\title{
Developing Innovative Students' Assignment Plans Based-on Tri Hita Karana Philosophy for Blended Setting
}

\author{
I Made Tegeh ${ }^{1}$, Anak Aging Gede Agung ${ }^{2}$, Ignatius I Wayan Suwatra ${ }^{3}$, \\ Luh Putu Putrini Mahadewi ${ }^{4}$ \\ \{imadetegehderana@yahoo.com ${ }^{1}$, agungtps2056@gmail.com², wayansuwatra3@gmail.com ${ }^{3}$, \\ putrini_mahadewi@yahoo.co.id ${ }^{4}$ \} \\ Universitas Pendidikan Ganesha, Indonesia ${ }^{1,2,3,4}$
}

\begin{abstract}
The purpose of this study was to determine the quality of the Innovative Student Work Plan (RTM) oriented to Tri Hita Karana in the blended learning model. Tri Hita Karana is a philosophy of life in Bali which consists of harmonious relations with God, between humans, and with the environment. RTM was developed using the models Dick, Carey and Carey. Six of this were developed, namely: RTM Group Counselling, Cinematography Education, Inferential Statistics, Mathematics Education, Learning and Instructional for Early Childhood, and Strategies and Learning Design. The questionnaire data collection method was employed. The data obtained were then descriptively analysed quantitatively. The results showed that the quality of RTM in the aspects of learning design was 82.50 , learning media was 100 , and that of assessment 64.44 . The result indicated that the quality of RTM was good and very good in the aspects of learning design and learning media respectively, but was just enough and needed revision in the assessment aspect.
\end{abstract}

Keywords: blended learning, innovative assignment plans, Tri Hita Karana Philosophy.

\section{Introduction}

The influence of information and communication technology (ICT) in the education sector is increasingly felt, in line with the shift from conventional face-to-face learning patterns to more open and media learning (Mukhoadhyay in Rusman, et al. 2012). At the moment, it shows symptoms that education in the future will be more flexible, open, and can be accessed from anywhere, at anytime, and by anyone. This can occur considering that currently, the internet network has been installed at all levels of the society.

In the present era of information technology, learning activities are no longer restricted by building walls. This is because ICT has opened a wide access to follow a more flexible learning activity. Likewise in the future, students from various schools and campuses will be able to take part in the same learning through online-based distance learning. The internet has made it possible to conduct more efficient distance learning by connecting students with instructors at different places. It also makes it easy for students to access materials, see their grades online, check progress in learning, view class schedules, send assignment files given by lecturers and so on.

The main factor in distance learning which has been considered a problem is the lack of interaction between educators and students. However, with internet media, it is possible to 
establish interaction between educators and students whether in real time or not. The real time form can be done for example in a remote discussion (chatroom), direct interaction with real audio, and online. An interaction not done in real time can be through messages (via email).

Internet is a technology used in realizing online learning. Haughey and Anderson (1998) revealed that there are three possibilities in the development of an internet-based learning system, namely: the web course is the complete use of the internet for learning activities; the web centric course is using the internet combined with distance learning and face to face (conventional); the web enhanced course model is the use of the internet to improve the quality of learning carried out in the classroom. The use of the internet in the education sector is still on the web enhanced course model. However, there are very few educational institutions that apply the web centric course model.

For students, the internet is no stranger. Latest research results show that the population of children and adolescents who are internet users in Indonesia is predicted to be as high as 30 million. As many as 98 percent of children and adolescents claimed to know about the internet, and 79.5 percent of them were users (tekno.kompas.com, 2014). The results of this study indicate that the internet is needed by all classes of people and is a great opportunity to be used for the needs of developing the quality of education and learning in higher education.

Given that teenagers are very familiar with the internet, it would be wiser to use it for their learning interests, as well as entertainment media. But what often occurs is the internet being more widely used as an entertainment medium in ways like chatting on social media, watching videos, playing games, and so on. Students are still very minimal using the internet for learning purposes. If this phenomenon continues to occur, students will prefer social media on the internet rather than choosing to study. This problem will result in a decline in learning activities and a deficiency in student learning outcomes. In addition to the wrongful use of the internet, learning in schools and colleges is still conventional. In other words, learning still relies on face to face.

To anticipate the inappropriate internet usage and lack of face-to-face learning, it is necessary to establish an e-learning portal and blended learning strategy that combines both face-to-face and online learning. Recent research findings indicated that Blended Learning (BL), a learning delivery strategy that combines the benefits of both modes of learning, is very functional in improving the quality of the learning process (Rosenthal \& Weitz, 2012; Florida, 2012). The emphasized development is the Tri Hita Karana Student Task Plan (RTM) which is implemented through blended learning. The development of RTM uses a dynamic intellectual learning (DIL) approach. DIL is oriented to prior-knowledge of each student so that it can be accessed without being limited by time and space, and to provide an opportunity for users to access different tasks and materials according to their respective abilities. DIL will provide opportunities for students to access assignments and subject matter according to their intellectual or learning speed. Those who are satisfactorily intelligent will be granted the opportunity to learn the next subject matter. The student can also continue to the next material if he has successfully completed the previous. This model will provide flexibility for all students to study according to their pace of learning. However, it is certainly very rare to find this in face-to-face learning which is often simultaneous and uniform.

The results of Dwaik's study, et al. (2016) depicted blended learning to have a positive impact on students. Its settings can improve student learning achievements both in quantity and quality. They also exhibited a positive attitude towards the implementation of this strategy. Research conducted by Suarni and Dantes (2012) regarding the implementation of dynamic intellectual learning (DIL) as one of the adaptive learning models showed that DIL provided flexibility for students to access learning materials according to their abilities. With this, the 
effective lecture time of 14 meetings can be utilised for other activities, such as assignments, group discussions, and practice in the field. This is not obtained in conventional learning.

Taking into account the results of these studies, the development of the innovative Tri Hita Karana RTM in the DIL blended learning model based on the Undiksha Education Faculty is a solution that is expected to overcome various problems, such as: 1) limited face-to-face learning between lecturers and students, 2 ) the limited freedom of students' learning according to their respective abilities, which have tended to be simultaneous and uniform, 3) underutilising ICT (internet) among lecturers and students for the purpose of learning, and 4) the manifestation of ICT-based learning climate. More specifically, the development of innovative content in the DIL-based blended learning model is also expected to have a significant impact on increasing students' thinking and learning outcomes in the Undiksha Education Faculty. Based on the above explanation, the main objective of this study is to determine the quality of innovative Tri Hita Karana RTM in Blended Learning Model Based on Dynamic Intellectual Learning Approach.

\section{Method}

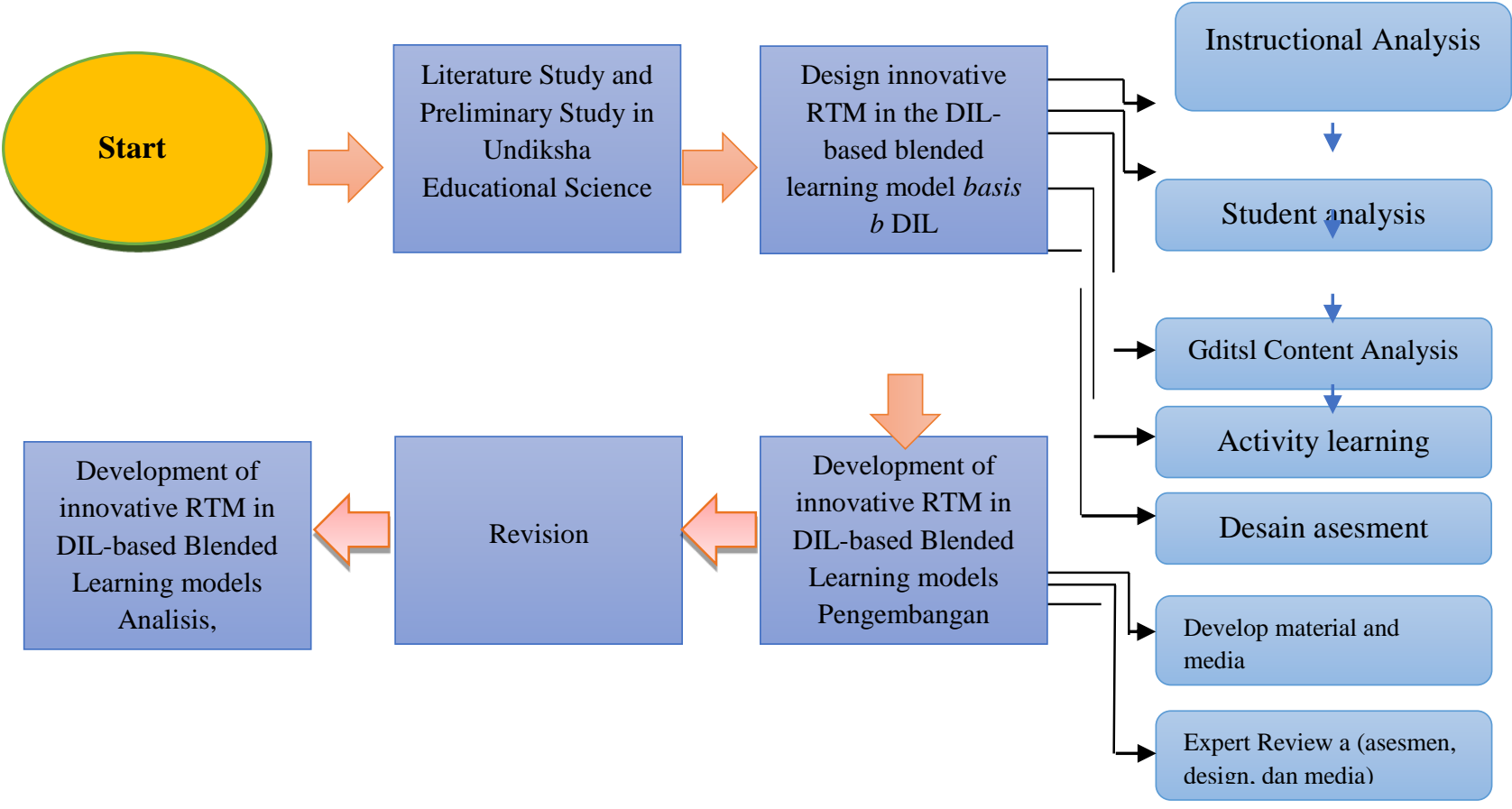

Fig 1. Flowchart of Research Implementation

This type of research is a development research. The product of this research is the Innovative RTM Student Task Plan Oriented Tri Hita Karana in the Blended Learning Model Based on the Dynamic Intellectual Learning Approach. To understand the path of research development, this can be visualized using the flow chart in Figure 1. 
The flow chart in Figure 1 is the general flow of research. In the development of innovative RTM using the models of Dick, Carey, and Carey (2005). Based on the models of Dick, Carey, and Carey, (2005), a design of the innovative RTM oriented Tri Hita Karana can be made in the blended learning model based on the DIL approach in Table 1.

Table 1 Innovative RTM Implementation Design in the Blended Learning Model

\begin{tabular}{|c|c|c|c|c|c|c|}
\hline \multicolumn{7}{|c|}{ Innovative RTM Implementation Design in the Blended Learning Model Learning } \\
\hline & \multicolumn{3}{|c|}{ Online Learning } & \multicolumn{3}{|c|}{ Face to Face Learning } \\
\hline \multirow{12}{*}{$\begin{array}{l}1 . \\
2 . \\
3 .\end{array}$} & $\begin{array}{c}\text { Environment } \\
\text { Learning }\end{array}$ & $\begin{array}{l}\text { Learning } \\
\text { Activity }\end{array}$ & $\begin{array}{c}\text { Content } \\
\text { Presentation } \\
\text { Model }\end{array}$ & $\begin{array}{c}\text { Learning } \\
\text { Environtmen }\end{array}$ & Learning Activity & $\begin{array}{c}\text { Model } \\
\text { Presentation } \\
\text { Model }\end{array}$ \\
\hline & Online based & Intoduction & Video & Classroom & 1. Introduction & Printed \\
\hline & computer & Example & Audio & Synchronous & 2. Group & (Teks book, \\
\hline & Synchronous & Exercise & Animation & Bidirectional & Presentation & Modul, \\
\hline & Aynchronous(email) & Self & Presentation & communication & 3. Exercises & Handout) \\
\hline & Bidirectional & Regulated & Media & & 4. Evaluation & \\
\hline & communication & Learning & (power & & & \\
\hline & & Discussion & point) & & & \\
\hline & & Group & Interaktive & & & \\
\hline & & Discuss & & & & \\
\hline & & 7. Homeworks & & & & \\
\hline & & Evaluation & & & & \\
\hline
\end{tabular}

Data was collected using questionnaires to determine the quality of RTM in learning design, learning media, and aspects of assessment. The datasets of this research can be accessed from https://osf.io/dkbe5/.

\section{Result}

The result of this development research is Tri Hita Karana's Innovative Task Plan (RTM). RTM is transformed into an online system to facilitate both face-to-face and online lectures. Figure 4.1 is an example of online learning design on the site e-learning.undiksha.ac.id in which RTM is presented. The developed RTM needs to be tested for design validity by learning design experts, media validity by instructional media experts, and the validity of its assessment by assessment experts. There were six TMS courses in validated blended learning, namely: 1) TMS Practice group counselling, 2) TMS learning and learning, 3) rTMS design and learning strategies, 4) rTMS inferential initiative, 5) rTMS mathematics and 6) rTMS cinematography education. Table 2 presents the quality of innovative RTM based on expert judgment. 


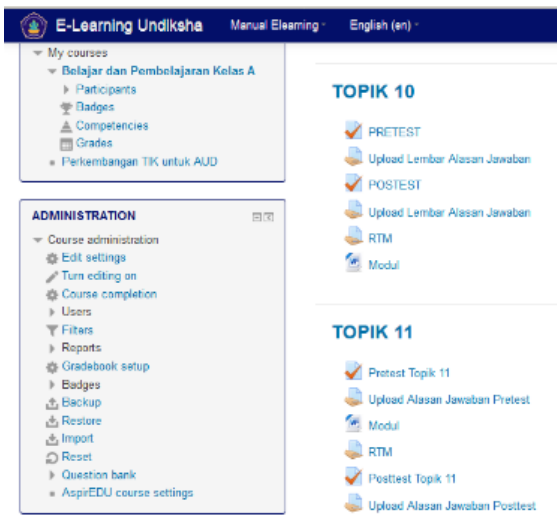

Fig 2. Content Presentation Type

Table 2. Quality of rTMS based on expert assessment

\begin{tabular}{llccc}
\hline \multirow{2}{*}{ No } & \multicolumn{1}{c}{ Name of RTM } & \multicolumn{3}{c}{ Validity Score } \\
\cline { 3 - 5 } & \multicolumn{1}{c}{$\begin{array}{c}\text { Instructional } \\
\text { Design Aspect }\end{array}$} & $\begin{array}{c}\text { Instructional } \\
\text { Media Aspect }\end{array}$ & $\begin{array}{c}\text { Assessment } \\
\text { Aspect }\end{array}$ \\
\hline 1. & RTM of Inferential Statistic & 75 & 100 & 86,67 \\
2. & $\begin{array}{l}\text { RTM of Learing and Instructional for Early } \\
\text { Childhood }\end{array}$ & 80 & 100 & 60,00 \\
3. & RTM of Mathematic & 90 & 100 & 66,7 \\
4. & RTM of Strategies and Learning & 75 & 100 & 66,67 \\
& Design & & & \\
5. & RTM of Education Sinematography & 92,50 & 100 & 55,33 \\
6. & RTM of Group Counseling & 82,50 & 100 & 55,33 \\
\hline & Average & 82,50 & 100 & 64,44 \\
\hline
\end{tabular}

Based on the table above, the mean score of innovative RTM on aspects of learning design was 82.50 (good), learning media was 100 (very good), and assessment was 64.44 (just enough).

\section{Discussion}

The quality of RTM in aspects of design, media, and assessment can be explained as follows. Its average score in the aspect of learning design is in the Good rating. In this aspect, RTM has been developed according to the needs of students so that the tasks presented are relevant to their ability. They have the freedom to select topics of lectures and partake in RTM according to their respective abilities. This plan is also developed in a face-to-face and online format that contains the contents of Tri Hita Karana values for students to be more flexible in carrying out their assignments. Likewise, the developed RTM has differences with TMS in general. The new emphasis is the value of Tri Hita Karana which consists of divine values, 
harmony with fellow humans and with the environment. Before working on assignments, students are expected to pray (implementation of divine values). Furthermore, the importance of cooperation, fair, and respectful division of tasks (values of harmony between people) while working on the assignment was emphasized. They must also pay attention to the surrounding environment, for instance, cleanliness of the work environment, comfort of the workplace, and occupational health (values of harmony with the environment). In the media aspect, RTM gets the Very Good rating, considering that it is designed in accordance with the message design rules. It is also designed to use matching letters and clear workflow tasks. In the aspect of assessment, it earned a rating that was influenced by a number of things, namely: (1) bills of cognitive, affective, and psychomotor duties were either unclear or not explicitly presented in RTM, (2) assessment criteria were incomplete, (3) schedule has not been made in the form of activities and time descriptions, and (4) the formulation of learning outcomes has not been completely written.

\section{Conclusion}

Based on the results of the experts' assessment, the validity of the innovative Tri Hita Karana-based RTM on the learning design aspects was 82.50 (good), the media aspect was 100 (very good), and the assessment aspect was 64.44 (just enough). In addition there were suggestions from experts to improve TMS developed primarily on aspects of assessment.

\section{Reference}

[1] Dick, W., Carey, L., \& Carey, J. O.: The systematic design of instruction. Boston: Pearson (2005)

[2] Dwaik, Raghad, Abdulmuti Jweiless, Salah Shrouf.: Using blended learning to enhance student learning in american literature courses. The Turkish Online Journal of Educational Technology. 15(2).126-137 (2016)

[3] Florida, J.: Analogy-integrated e-learning module: Facilitating students' conceptual understanding. Journal of Computers in Mathematics and Science Teaching, 31(2), 139-157 (2010)

[4] Rosenthal, D. \& Weitz, R.: Large-course redesign via blended learning: A postimplementation assessment across institutions. International Journal on E-Learning, 11(2), 189-207 (2010)

[5] Rusman, Kuriniawan, D., \& Riayan, Cepi.: Pembelajaran berbasis teknologiiInformasi dan komunikasi: Mengembangkan profesionalisme guru. Jakarta: PT Rajagrafindo Persada (2011)

[6] Suarni, Ni Ketut \& Rasben Dantes, Gede.: Implementasi dynamic intelectual learning

(dil) sebagai salah satu adaptive learning model. Jurnal Sains dan Teknologi, 1(1) (2012) 